5. Olga Herfelder-Polschin: Verbranntes Denken - verbrannte Sprache. Übersetzung und Rezeption des philosophischen Werkes von N. Berdjaev in Deutschland. Berlin 2013. S. 97.

DOI https://doi.org/10.30525/978-9934-588-90-7-65

\title{
НЕОКЛАСИЦИЗМ І АКМЕЇЗМ: ГЕРОЙ У ВИБРАНІЙ ПОЕЗІЇ МАКСИМА РИЛЬСЬКОГО І МИКОЛИ ГУМІЛЬОВА (СИМВОЛ, ПЕРЕКЛАДОЗНАВЧИЙ АСПЕКТ)
}

\author{
Смольницька О. О. \\ кандидат філософських наук, член ІСОМ, \\ провідний науковий співробітник \\ Киїський літературно-меморіальний музей Максима Рильського \\ м. Київ, Украӥна
}

Подібні риси українського неокласицизму і російського акмеїзму (як і схожість «п'ятірного грона» з іншими течіями тощо) вже виокремлювались у вітчизняній гуманітаристиці [8-11], проте інтуїтивний поетичний діалог Миколи Гумільова (1886-1921) і раннього Максима Рильського (1895-1964) іще докладно не розглядався. Відтак, пропонується здійснити компаративний аналіз.

Матеріал аналізу: вибрана рання лірика М. Рильського, оригінал вірша М. Гумільова «Старый конквистадор» (1908 р., зі збірки 1918 р. «Жемчуга», у перекладі М. Стріхи назва - «Перлини»; до того книга виходила 1910 р. [12, с. 725]) та україномовні поетичні переклади: 1) М. Стріхи, 2) неопублікований переклад авторки цих рядків (див. додаток). Обидва переклади здійснені незалежно один від одного. Пропонується компаративний, символогічний, текстологічний, перекладознавчий аналіз. Переклад М. Стріхи береться до уваги як переважно точний; до того ж, цей український текст демонструє зв'язок літературних поколінь - неокласиків та їхніх учнів.

Нахил неокласиків до точності, елітарних здобутків парнасизму звідси про мороз як «душу парнаського співця» [3, с. 217] (в оригіналі ці слова - 3 авторською розрядкою [6, с. 57]) зумовлює творчий пошук М. Рильським і поетові вислови на кшталт у «Срібному сонеті»: «Цей вечір, замкнений в холодному спокої, / Ясний, докінчений нагадує сонет...» [6, с. 85]. Або «сьомий неокласик» І. Качуровський (19182013), аналізуючи «В високій келії, самотньо-таємничій...» і докладно 
цитуючи твір [3, с. 221-222], підсумував на основі цього вірша неокласичний принцип: «...мистецтво - вище від життя» [3, с. 221], недарма: «Не Бог, не сатана витає наді мною [цитується відповідно до нових правописних норм. - O. С.], / А інший, дивний дух на все кладе печать / Прозорої краси і срібного спокою, / Яких земним устам не чуть i не назвать» [6, с. 53]. Відтак, ці твори можуть свідчити і про відгомін ідеї der Übermensch'a (про ніцшеанство, надлюдину та інші питання української літератури, зокрема, у працях С. Павличко [5, с. 193] та: [2], [8], [10]).

У зв'язку 3 цим варто порівняти гумільовського «Старого конквистадора». Перша строфа оригіналу: «Углубясь в неведомые горы, / Заблудился старый конвистадор, / В дымном небе плавали кондоры, / Нависали снежные громады» [1, с. 128]. Інверсію тут ужито вдало, 3 оповідною інтонацією (замість «Старый конквистадор заблудился» «Заблудился старый конвистадор»), яка викликає довіру. 3 метою відтворення колориту епохи у додатку збережено застаріле написання i вимову слів, яких дотримувався поет: конквіста́dор (замість конкістадо́р), кондо́ри (замість ко́ндори). В оригіналі вжито неточну риму: конквистадор - громады. У перекладі М. Стріхи наявна спроба наблизити римування до оригінального, водночас вибір точніший формально, хоча змістовно відступає (у цитаті курсив мій. - O.C.): «Навкруги круті незнані гори, / Де снізи перетина екватор; / Висли в небі димному кондори, / Заблукав у горах конквістадор» [12, с. 725]. Інтонації завдяки інверсії дотримано, натомість додано риму «екватор»«конквістадор». Згадка про екватор уточнює географію топосу, тоді як в оригіналі гори можуть бути узагальненими, завдяки образу конкістадора можна лише здогадуватися про Південну Америку. Другий рядок «Заблудился старый конквистадор» у перекладі переміщено і зроблено кінцевим (четвертим), але це оптимальне рішення (перестановка) для збереження авторської ідеї, оскільки в українській мові зі словом «громада» передовсім виникне асоціація 3 людським об'єднанням. (Дослідження на тему перекладацьких трансформацій, але на прикладі «Кентерберійських оповідей» Дж. Чосера у перекладі М. Стріхи: [4]).

Друга строфа: «Восемь дней скитался он без пищи, / Конь издох, но под большим уступом / Он нашел уютное жилище, / Чтоб не разлучаться с милым трупом» [1, с. 128]. М. Стріха це відтворив без уточнення часового проміжку, не згадуючи про «вісім днів», тобто застосувавши вилучення, але вдало компенсувавщи прислівником «навмання»: «Навмання він довго йшов без їжі...» [12, с. 726]. Натомість у третьому рядку знайдено точну риму «хижу» до слова «їжі»: «Він знайшов собі 
затишну хижу» $[12$, с. 726]. Хижа змістовно наближена до абстрактного жилище. Цікаво, що герой М. Рильського (сонет «У горах, серед каменю й снігів...», 1922 р.) бачить у засніжених скелях, як «Малюється на синім небі чітко / Мисливська хатка, притулок орлів»- де дружнє коло («ми») збирається, їсть і грає у шахи [6, с. 23]. У третій строфі російського оригіналу наявний біблійний підтекст: «Там он жил в тени сухих смоковниц...» [1, с. 128]. Відповідно, можна згадати старозавітного Йону, який після звільнення з китового черева рятувався від спеки під деревом (або «тиквою» [7, с. 1044), що невдовзі засохло (Йона, 4: 6-7]). Образ-символ смоківниці - новозавітний (притча про неплідну смоківницю, Лк., 13:6-9 [7, с. 94]). У перекладі М. Стріхи - вилучення згадки про смоківнищі: «Під гіллям усохлим наостанок...» [12, с. 726]. Так само у моєму перекладі через еквіритмічність випущено про те, що смоківниці були саме всохлі. У цитованому перекладі збережено ознаку всохлості, але не названо (не конкретизовано) дерева, проте лексема «наостанок» дозволяє наступну точну (відповідну до оригіналу) риму «коханок» $[12$, с. 726$]$, бо в акмеїста римується «смоковниц» «любовниц» (у моєму перекладі - узагальнено: «дівиці»).

Наступна строфа важлива характеристикою героя: «Как всегда, был дерзок и спокоен / И не знал ни ужаса, ни злости, / Смерть пришла, и предложил ей воин / Поиграть в изломанные кости» [1, с. 128]. У М. Стріхи: «Ні від кого не чекав поради / I не знав, ні страху, ані злості» [12, с. 726] (тобто тут вилучено «дерзок і спокоен», але замінено на самодостатність: герой ні на кого не сподівається, окрім себе). Рима «зіграти» неточна до «поради», але приблизна. Лексему «воїн» («воин») випущено (як і у моєму перекладі), тому заключні рядки тут: «Смерть прийшла, і запросив зіграти / Він іï у вищерблені кості» [12, с. 726]. Фінальна характеристика героя як воїна відсутня, але зміст і форму (а, отже, й ідею) збережено. У М. Рильського (сонет «У горах, серед каменю й снігів...») кода стверджує: «Так ми, - як день розквітне молодий, - / Підем зі смертю в шахи погуляти, / Ступаючи по стежці кам'яній» [6, с. 23]. Тут бачимо мотив гри зі смертю. Гра у шахи (кості, карти...) зі смертю - поширений фольклорний, а відтак і мистецький мотив i в орієнтальній, і у західній традиціях (одна із інтерпретацій - гра козака у пеклі з чортами у дурня - гоголівська «Пропала грамота»). Але кості базуються на жеребі (випадку), шахи - на правилах. У М. Рильського помітно чіткість, віру в ratio (помітне у неокласиків - звідси їхне прагнення точності як запоруки перемогти хаос), його персонажі інтелектуали, у М. Гумільова на першому плані у цитованому вірші авантюрність. У М. Рильського герої порівнюються 3 байронівським 
Манфредом, що: «В такій же хаті... відпочив, / Щоб знов на прю із фатумом устати» [6, с. 23] - в акмеїста конквістадор зустрічається зі смертю, тобто бачить свій кінець. Але пропозиція востанне пограти у кості (тобто стати на прю) створює відкритий фінал. Отже, для активних персонажів неокласика усамітнення у горах - тимчасовий відпочинок, для активного гумільовського героя - вічний.

Таким чином, перекладознавчий аналіз (розгляд перекладацьких трансформацій) дозволив більше звернути увагу на компаративний аспект. герой М. Гумільова, конкістадор (частий типаж у цій ліриці, авторське alter ego), грає зі смертю. Поступово втративши все матеріальне, «старий конквістадор» не втрачає авантюрного духу власне, того, що й спонукало до відкриттів. Це не бравада, а пізнання життя і смерті, цебто танатологічний аспект не є тут єдиним. Так само герой М. Рильського пізнав сутність життя і смерті, а, отже, вічність. Він розуміє небезпеку смерті, але завдяки набутій мудрості (інтенсивному духовному пошуку) вже не боїться ііі. Але знову ж таки не вдається до сліпого нерозрізнення. Важливо і те: якщо гумільовський конкістадор самотній і поступово все втрачає (у тому числі коня як вірного друга), то неокласичний герой як самітник (добровільний; в акмеїста - жертва обставин), так і сильний завдяки дружньому чи колегіальному колу однодумців - «ми». Якщо конквістадор - авантюрист, то у М. Рильського ліричний герой і взагалі персонаж часто передусім поет, а ще мислитель. Гумільовський герой «дерзок и спокоен» - для персонажа неокласика важливе як пізнання життя, так і усамітнення, а у мистецтві «прозора краса і срібний спокій», причому це наголошується і в інших поезіях періоду 20-х рр. ХХ ст.

Додаток. Микола Гумільов, «Старий конквістадор» (переклад Ольги Смольнищької, 2013). В таємничі віддалившись гори, / Конквіста́дор раптом загубився, / В димнім небі плавали кондо́ри, / Нависали снігокручі висі. // Вісім днів блукав старий самітний, / Здох румак, та врешті під уступом / Він знайшов притулок непомітний, / Щоб не розлучатись 3 милим трупом. // Там він жив під тінню смоківниці, / І співав про сонячну Кастилью, / I бої ввижались, і дівиці, / Бачив то пищалі, то мантильї. // Як завжди, у спокої звитяжний, / Він не знав ні жаху, ані злості, / Смерть прийшла, і запросив одважний / Грати з ним у визублені кості.

\section{Література:}

1. Гумилев Н. С. 58. Старый конквистадор. Гумилев Н. С. Стихотворения и поэмы / Вступ. ст. А. И. Павловского. Биогр. очерк 
В. В. Карпова. Сост., подг. текста и примеч. М. Д. Эльзона. Ленинград: Сов. писатель, 1988. С. 128.

2. Заїка Т. П. (2015). Українська література кіния XIX - початку ХХ століття в контексті західноєвропейської модерної культурної nарадигми. Дисертація на здобуття наукового ступеня кандидата філософських наук. Київський національний університет імені Тараса Шевченка. 193 с.

3. Качуровський I. Променисті сильвети : лекції, доповіді, статті, есеї, розвідки; Передм. М. Слабошпицького. К. : Вид. дім «КиєвоМогилянська академія», 2008. 766 с.

4. Кириченко А. С. Образи класичної британської літератури як лінгвокультурні типажі: перекладознавчий аспект: Магістерська дисертація на здобуття ступеня магістра зі спеціальності 035«Філологія» студентки 2 курсу, групи ЛА-371 МП Національного технічного університету України «Київський Політехнічний інститут імені Ігоря Сікорського» (факультет лінгвістики, кафедра теорії, практики та перекладу англійської мови) (науковий керівник доцент, канд. пед. н. Демиденко О. П.). К., 2018. 130 с.

5. Павличко С. Дискурс модернізму в українській літературі: Монографія. 2-ге вид., перероб. і доп. К. : Либідь, 1999. 447 с.

6. Рильський М. Під осінніми зорями. Друга книжка лірики. Вид. 2-ге, перероблене. Репринтне відтворення видання 1926 р. К. : Абрис, 2000. 104 с.

7. Святе Письмо Старого та Нового Завіту. Повний переклад, здійснений за оригінальними єврейськими, арамійськими та грецькими текстами. Ukrainian Bible 63 DC. United Bible Societies 1990. 55 M. 1435 c.

8. Смольницька О. О. Ідея надлюдини у Лесі Українки і ліриці Максима Рильського порівняно 3 драматургією Генріка Ібсена. Онтологічні виміри сучасної філології: Матеріали міжнародної науковопрактичної конференції, м. Київ, 24-25 вересня 2020 р. К. : Таврійський національний університет імені В. І. Вернадського, 2020. С. 100-106. Смольницька О. О. Класичний міф: акмеїзм - неокласицизм - «Празька школа». Філософія $і$ художня культура у хронотопі технічного вузу: Матеріали II Міжнародної науково-практичної конферениії (12 грудня 2019 р., м. Київ) / Укладачі: Новіков Б. В., Покулита І. К., Гавва О. В. К. : Вид-во Ліра-К, 2019. С. 131-134.

9. Смольницька О. Максим Рильський i творче покоління fin de siècle: сублімація та феномен надлюдини. Одинадията міжнародна науково-практична Інтернет-конференція "Діалог мов - діалог культур. Украӥна і світ» (29 жовтня - 1 листопада 2020 року) - XI Internationale 
virtuelle Konferenz der Ukrainistik "Dialog der Sprachen - Dialog der Kulturen. Die Ukraine aus globaler Sicht". Internationale virtuelle Konferenz der Ukrainistik - Мюнхен, Університет Людвіта-Максиміліана (LudwigMaximilians-Universität München). URL: http://www.ukrainistikkonferenz.slavistik.lmu.del

10. Смольницька О. Переклад сонета на прикладі трьох хвиль українського неокласицизму: виклики і невідкриті тексти. Поетичні та віршознавчі заповіти Ігоря Качуровського: До 100-річчя від дня народження: Всеукраӥнський віршознавчий семінар. Київ. 28-29 вересня 2018 року. К.: Видавничий дім Дмитра Бураго, 2018. С. 83-102.

11. Стріха М. Улюблені переклади. Вид. 2-ге, випр. і доповнене. К. : Пенмен, 2017. 770 с.

DOI https://doi.org/10.30525/978-9934-588-90-7-66

\section{ПЕРЕКЛАДАЦЬКИЙ АНАЛІЗ ТРАНСФОРМАЦІЙ: ЧЛЕНУВАННЯ ТА ОБ'СДНАННЯ РЕЧЕНЬ ПРИ ПЕРЕКЛАДІ РОМАНУ “ТНЕ LORD OF THE RINGS" ДЖОНА РОНАЛЬДА РУЕЛА}

\section{Тарасюк А. М.}

асистент кафедри романо-германської філології та перекладу Білочерківський начіональний аграрний університет м. Біла Церква, Київська область, Україна

Необхідність застосування синтаксичних трансформацій у перекладі, як правило, зумовлена особливостями актантної структури речень мови оригіналу та мови перекладу.

Причини застосування перекладацьких синтаксичних трансформацій викликані відсутністю певних еквівалентів в українській мові, фіксований порядок членів речення англійської мови так як в українській він, порядок слів визначається відносною довільністю. Синтаксичні трансформації використовуються для передачі більш логічного смислу тексту оригіналу i зумовлені мовними нормами побудови синтаксичної одиниці [3].

Об'єднання речень - трансформація протилежна членуванню. Це спосіб перекладу при якому синтаксична структура в оригіналі перетворюється шляхом з'єднання двох чи більше простих речень[2]. Наприклад: 